\title{
J. William Fulbright--Belief Systems, Models of Representation and Re-election Strategies, 1942-1962
}

\author{
KURT K. TWERASER \\ University of Arkansas/Fayetteville
}

Most people remember Senator Fulbright as the great dissenter, the administration pariah, the vehement critic of the Vietnam war. There is more to the Fulbright puzzle than the distressed foreign affairs internationalists who turned to heresy. He was, before his conversion to an outspoken limitationism (Brown, 1985), a reflective man who shunned rather than sought the public spotlight, a party loyalist who preferred to exert influence from within, faithful supporter of NATO and the Atlantic Community, defender of foreign aid, even floor manager of the Tonkin Gulf resolution as a believer in the need for strong presidential leadership. Domestically, though, he was a middle-of-the-roader whose natural sym pathies were for tradition and order, rather than for iconoclasm and rebellion.

In order to fill in some pieces of the jigsaw puzzle, I propose to analyze the relationship between certain aspects of Fulbright's belief system and his models of representation during the period ranging from his first election to the U.S. Congress in 1942 to his re-election to the U.S. Senate in 1962, before the Vietnam war forced Fulbright into a major re-examination and realignment of his beliefs on international politics.

Fulbright appears to be a pragmatist in his approach to politics in general (Johnson \& Gwertzman, 1968), an internationalist in foreign affairs (Tweraser, 1974), a traditionalist on race. How, then, can we explain differences between Fulbright, the foreign policy legislator, the politico in domestic politics, and the supporter of segregation in race politics? Legislators are forced by the very nature of their profession to deal efficiently with a number of issue areas. Each issue area can be conceived of as a psychological environment potentially activating different cognitive styles, different self-images, different models of representation, different models of decision-making, and different manner of commitment to institutions. It has been convincingly demonstrated by Clausen that legislators make decisions by adjusting their decision rules (whether to act according to the wishes of the President, or in line with the party majority, or according to their own conscience) to the policy dimension to which they believe a particular issue belongs (Clausen, 1973). While he differentiates five dimensions (government management, social welfare, agricultural assistance, international involvement, civil liberties), I adopted a simplified trichotomous construct consisting of a foreign policy issue area, the race issue area, and other domestic issues collapsed into a residual issue area, public welfare, following the research strategy sketched out by Miller and Stokes (1963) in their seminal article on constituency influence in Congress.

Based on roll call and interview items, they focused on a social welfare dimension, the primary domestic issue of the New Deal-Fair Deal and New Frontier areas, including in it such issues as public housing, public power, aid to education, and government's role in maintaining full employment. Their second dimension dealt with support for American involvement in foreign affairs, including the issues of foreign economic aid, military aid, military intervention. There third dimension, civil rights, comprised the issues of school desegregation, fair employment, and the protection of black voting rights. While Miller and Stokes clearly established that a congressman's roll-call behavior is strongly influenced by his own policy preferences 
and by his perception of preferences held by the constituency, they also concluded that no single configuration of perceptions links representative and constituency but rather several distinct patterns determined by the issue area.

Thus, legislators adopt models of representation of constituency interests, ranging from trustee to politico to instructed delegate (Wahlke, Eulau, Buchanan and Ferguson, 1962). The various models reflect different beliefs about social distance-that is, the proper status relationship between representative and represented in different issue areas (Eulau, 1967). Legislators manage to eliminate role strains by assigning different status to their constituencies depending on the issue area. In one issue area, they may subordinate themselves entirely to their constituency as instructed delegates, in other areas they may believe in superior status for themselves, in still others, they may strike a bargain between trustee and delegate tending toward the role of politico.

Distinctively different models, then, describe a representative's approaches to the three policy areas. Assuredly, the scheme lacks empirical validation and the possibility that it may reflect more the judgments of this observer than a representative's cannot be excluded. The trichotomy certainly does injustice to the richness of empirical reality which probably is better caught through the use of continua on which actors can be plotted.

Focusing on Fulbright's models of representation, clearly we must recognize that legislators, like everyone else, cannot afford to re-examine their philosophy every time an issue arises. They have to make preliminary general decisions about their basic responsibilities in order to tackle efficiently the myriad of subsequent specific choices. Thus, role definition becomes important--the attempt by a politician to define appropriate be havior for himself in a situation not totally structured by institutions and society (Barber, 1964). As the roles attached to the office of legislator are ambiguous and nowhere officially laid down, it is up to the in dividual legislator to define his own and develop strategies of accommodation to the influences which press upon him.

One of the linkages between role conception and the substance of legislative behavior lies in the degree to which legislators look to their constituencies as referents. Yet, political scientists have long been in the habit of treating role conceptions of legislators as if they were unrelated to their political home base (Pitkin, 1972). Recently, Richard Fenno demonstrated that delegate and trustee conceptions persist side by side in the individual legislator because the sets of constituent attitudes on which each depends also exist side by side (Fenno, 1978). Voters want delegate behavior on matters most important to them and trustee behavior on all others. For the individual legislator, the problem is how to obtain legitimation for his Washington behavior back home. The categories of delegate, politico and trustee, apart from being guidelines for the legislator, serve also the function of legitimizing vehicles for convincing various constituencies of the legislator's continued qualifications for his job, and of his identification with, and empathy for them. How, then, did Fulbright approach the vexing problems of representation?

\section{The Fulbright Approaches to Representation}

The strains arising out of Fulbright's endeavor to represent others in the political process are intimately connected with his view of human nature and the nature of politics in general. Fulbright believed that people are usually moved by irrational forces. Man's irrationality is a product of his biological heritage in which 
aggressive instincts are stronger than the desire for peace (Fulbright, 1967). This rather pessimistic view of human nature is balanced by his belief that man is also endowed with reason, which may help him to acknowledge his animal inheritance and thereby control it (Fulbright, 1966). Certainly, the very fact that Fulbright remained in politics from 1943 to 1974 --and then left only involuntarily--is a powerful indicator that he believes human beings are endowed with some capability for choice. We might say that history consists for Fulbright of man's endeavor to control irrationability, although he often complained that "there is nothing very rational about politics, internal or external" (Fulbright, 1960a).

Already as President of the University of Arkansas (1939-1941), Fulbright vigorously asserted that manifestations of irrationality had to be tackled in a rational manner. Arkansas' developmental imbalance, plagued as the state was by outside economic domination, internal corruption, and poverty, could be rectified by a dose of rationality in the form of educa tion and political leadership. History, even Arkansas history, was not made by large interests and organizations alone. The individual, properly educated and wisely led, could overcome the confining conditions of underdevelopment (Fulbright, 1939).

In domestic politics, abuses of power could be counteracted by education and rules which check the perennial struggle for influence between the branches of government; (Fulbright, 1951) but in foreign policy, the constitutional arrangements for political adjustments were clearly inadequate "in a world that obstinately refuses to conduct its affairs under Anglo-Saxon rules of measured and orderly procedures" (Fulbright, 1961). Rationality could not be brought to bear upon international affairs through a system in which power and responsibility for foreign policy were shared and overlapping and thus unable to produce unified policies oriented to a clear and definite conception of national purpose.

Even more somber was the note he struck in commenting on the race question in the South.

History tells us that race memories long endure. They are sentimental and emotional, and when stirred up, they become irrational ... Bearing in mind that flesh and blood is weak and frail, these problems might yield to the slow conversion of the human heart rather than the remedies of a more urgent nature (Fulbright, 1958).

It appeared to him a constant in human affairs that whenever social convictions are profoundly violated, human beings are "likely to react almost by involuntary reflex and often violently."

An insecure person would have probably faltered under the impact of these contradictions, but politicians are made of sturdy stuff. Fulbright, like other legislators, solved the question of the proper mix between what he conceived to be the demands of efficiency in government and public accountability by developing a self-image which enabled him to develop different beliefs for different issue areas. In dealing with the question of whether a representative must do what his constituents want, or what he thinks best, he was able to define for himself relationships to his constituents, to the nation, and to his own conscience that remained fairly stable throughout his career (Fulbright, 1946, 1963).

Fulbright quite self-consciously delineated the boundaries within which choices were possible, and what the social and personal implications of these alternatives were for him:

The legislator's relationship with his constituency is, in most cases, the dominant influence in his political life. It is only natural that his constituents look upon him as their personal representative at the seat of government. It requires a high degree of political maturity and intellectual objectivity for them to regard the man they elected as an officer of the National Government (Fulbright, 1946). 
He then warned against oversimplifying the functions of a member of Congress, bringing out particularly well the ambiguities in which an elected official, trying to legislate rationally, often finds himself. Either he is in the position of a lost hunter seeking direction or he is subject to heavy pressure from different directions (Mitchell, 1958). Reflecting on this source of ambiguity, Fulbright testified to the

.mental torture (which Congressmen go through) in their effort to reconcile the interests of their constituents with the demands of fellow members and their conception of the national welfare. It is very easy for the citizen back home to have a positive and complete answer for every question. . . He has not heard the other side. . He simply cannot understand why his representative hesitates and compromises with his colleagues... The legislator...finds himself caught between the heavy pressure of the advice from home pushing him in one direction and the pressure from his colleagues pushing him in the opposite direction. The result, necessarily is a compromise in which the facts and the judgment of the legislator play a large par (Fulbright, 1946).

Fulbright was, of course, aware of expectations that went so overwhelmingly in one direction that independent action was deterred; he argued skillfully;

\begin{abstract}
The average legislator, early in his career, discovers that there are certain interests or prejudice of his constituents which are dangerous to trifle with. Some of these prejudices may not be 0 fundamental importance to the welfare of the Nation, in which case he is justified in humoring them, even though he may disapprove. The difficult case is where the prejudice concern fundamental policy affecting the national welfare (Fulbright, 1946).
\end{abstract}

As an example of a constituency-dominated issue, he used the poll tax, the abolitior of which, in his judgment, would not cure any major problems. Isolationism he singled out as the issue worthy of risking his career over;

...regardless of how strongly opposed my constituents may prove to be to the creation of, an participation in, an even stronger United Nations Organization, I could not follow such policy in that field unless it becomes clearly hopeless (Fulbright, 1946).

In his self-image, Fulbright adopted diametrically opposed conceptions representation for two important issue areas: the instructed-delegate model for civi rights, submitting entirely to popular mandate; and a model for foreign policymakin close to the concept of representation generally associated with Edmund Burke refusing to serve the constituency's will though not its interests. Foreign policy wa an issue area which must be subject to the rational deliberations of wise statesmen the superior wisdom presumably either residing in himself or the executiv (Fulbright, 1964). In questions calling for expertise, there was no point in countin noses among the constituents.

In civil rights, Fulbright did not claim either for himself or the nationa government any superior wisdom vis-a-vis the constituents. It struck him a unjustifiable to ignore the opinions of the people, for irrational commitment 0 personal preference were involved rather than deliberation. A violation of what $h$ believed the proper status relationship in civil rights was apt to trigger rather vigorou responses, accusing those who upset that relationship of the vice of intellectua arrogance. For example, in answer to an article praising Fulbright as a true liber: because of his independence, the Senator found himself, not unexpectedly, complete agreement and he mused:

I have often thought how paradoxical it is that men like Humphrey are called liberal when fact they are the most intolerant and dictatorial members of the Senate. They...known all the answers to all of the problems and are quite willing to use all of the forces at the command to compel obedience to their will (Fulbright, 1950a).

If local interests needed defense against a threatening central power, Fulbrigl discovered readily the virtues of the mandate position; if the national interest neede defense against threatening parochial interests, Fulbright sang the praises c trusteeship. Between these two poles, there was a vast realm of issues in which th rationality-irrationality test could not be applied so easily. In the public welfar 


\section{Models of Representation and Re-election Strategies, 1942-1962}

dimension, Fulbright's model of representation was that of the politico striking bargains between the national and his constituency interests. Fulbright was a good provider for Arkansas, craftily using the opportunities open to a resourceful politician with an effective staff in an incremental decision-making process. It is hard to pin any ideological label on him in this issue-area.

Fulbright acquired the political coloration of an old-fashioned rural liberalism that was suspicious of organized labor but wedded to the idea of federal aid for power dams, rural electrification, irrigation, and education. Although generally liberal in economic policy, he was not committed to any ideological doctrine and knew the value of making common cause with private economic interests. In general, he went along with the wishes of the national party leadership with significant modifications due to local interests. Examples from this ambiguous dimension would be Fulbright's approval of federal aid to education with the important proviso that the dispensation of the funds ought not to be controlled by Washington. Aid to small business was probably the item in this dimension causing the least problem; such aid would be of benefit to Arkansas and was advocated by the national Democratic party. He was a liberal in that he was generally willing to invest public agencies with new powers and augmented authority, was not necessarily adverse to increased taxes, and occasionally criticized private enterprise and entrenched interests. On the other hand, he was a Southern conservative, occasionally insisting that federal instruments had too much power, and that both decision making and revenues should be redistributed to state legislatures and local communities with no strings attached.

It is interesting to note that different models of representation go together with different styles of reasoning. This variability is, of course, most pronounced in the two areas furthest removed in terms of the degree of governmental centralization Fulbright believed appropriate. In civil rights, the delegate model was matched by a philosophical stance of traditionalism--references to the South and to the southern mind abound. Occasionally, the South assumes the form of a past utopia--almost a Paradise Lost--providing a standard to judge adversely certain developments engendered by modernization, urbanization, and industrialization (Fulbright, 19531954). The race issue is invariably placed in a historical-philosophical context, the judgment on human nature is extremely pessimistic, the issue is not believed susceptible to political solution but must be left to the healing influence of time, education, and the slow conversion of the human heart. The criterion for government policy is social acceptability. Consequently, the most effective policy is no policy.

In foreign policy, the representational model of trusteeship was associated with a pronounced universalistic style. Parochial interests were rejected as possible criteria for judging policy, political acceptability of a policy was subordinated to efficiency. His image of the proper institution to make foreign policy was clearly influenced by the rational actor model. Echoing Alexis de Tocqueville, Fulbright asserted that democracies were inherently at a disadvantage in foreign policy, since the only foreign policy a democracy could successfully engage in--an isolationist one--was no longer possible. Domestic acceptability narrowed the range of choices open to the Executive; coalition diplomacy tended to concentrate foreign affairs powers in the hands of the President and downgrade the role of Congress and the electorate. Due to the complexity of the subject matter, the age of the foreign policy amateur was over.

Fulbright compared the almost unmanageable American governmental machinery with what he believed to be the advantages of a monolithic authoritarian state, such as the Soviet Union, in foreign policy. Moreover, in the Soviet Union, the people who participated in the decision-making process had a very clear conception of their role in the world. In the United States' system, in which power and 


\section{Kurt K. Tweraser}

responsibility for foreign policy were shared and overlapping, no unified policies could be devised. The workings of the sprawling administrative apparatus and the checks and balances of congressional authority in foreign relations imposed serious restraints upon rational policy-making. Therefore, he believed that the price of democratic survival in a world of aggressive totalitarianism is to give up some of the democratic luxuries of the past, however, distasteful and dangerous it may be to vest the Executive with powers unchecked and unbalanced (Fulbright, 1961)1.

It should be emphasized that constituency demands are but one set of relationships influencing legislative behavior. The legislature itself, with its peculiar committee structure, is a potent source of influence upon the behavior of legislators. The legislator's success as a professional depends partially upon his conforming to the expectations held by his colleagues. As Fulbright put it, "The effectiveness of a Member depends to a considerable extent upon his ability to gain the respect of his colleagues. In open debate and in Committee, it is not easy to deceive them..." (Fulbright, 1946).

Fulbright was clearly aware that the American polity disperses power so much that no one official is able to accomplish a task without the cooperation of other officials, who may have different values and goals and may, in addition, belong to a different party. Gaining the respect of one's peers by demonstrating expertise in representing specific constituency in terests is one way of reducing this particular role strain of diffused responsibility and limited controls over outcomes.

Another source of strain in the bundle of legislative roles is the sheer number of demands made on the time of the legislator. Fulbright put it this way:

\footnotetext{
...the fact is that the multitude of requests of minor personal services comes close to destroying the effectiveness of a great many capable representatives...no time (is) left for the intelligent study and reflection that sound legislation requires (Fulbright, 1946).
}

This suggests that Fulbright felt frustrated in his sense of legislative efficacy by the pressure of time and conflicting demands of the situation. He felt that petty demands prevented him from properly performing a job of considerable responsibility.

A further strain was the insecurity growing out of the low status accorded the politician in the American culture.

Americans complain of the ineptness of the Government, but at the same time they are supercilious, if not contemptuous, toward those who devote their energies to its service....A legislator, like other people, has no ego that requires expression and recognition if it is to avoid become warped and eccentric. Like other human beings, he desires the approval of his fellowmen, and if this is denied him, he tends to become cynical and disillusioned. It is truly unfortunate that the people do not understand more clearly the real function of the legislator (Fulbright, 1946).

There is a certain defensiveness in that statement indicating that Fulbright was not only interested in correcting the public's view of him but in sustaining his self image as a useful member of society.

Thus Fulbright experienced considerable role strains, such as mandate uncertainty and status insecurity, but was, on the whole, quite able to deal successfully with them, bearing out the judgment that "successful adaptation to legislative life depends not on the absence of adjustive problems but on the capacity to deal with them effectively" (Barber, 1967).

These diverse pressures briefly described reflect the complex world of the Senator. It is a world of high public expectations--to answer every constituent's letter, to find the elderly citizen's lost Social Security check, to follow the most ethical standards of public conduct, to avoid undue relationships with representatives of organized interests. It is a daily fact of life for senators: they are representatives of 


\section{Models of Representation and Re-election Strategies, 1942-1962}

individual voters, and at the same time somehow are expected to equip themselves and behave as statesmen. A good many voters do not know what is local government and what is national, especially in foreign policy. It is an old, but nevertheless correct truism that there is little or no mileage to be gained in the constituency from senatorial prominence in foreign policy. Senators, certainly, recognize the need to reiterate to constituents what they understand them to be saying--that is, to attempt to articulate constituent anxieties, to define constituent problems in terms constituents can understand. At no time is this need more urgently felt than during election time. It is also the occasion when the models of representation face their most acid test.

\section{Models of Representation and Elections}

Fulbright's primary constituency must be viewed particularly in the light of Arkansas factional politics. Arkansas, being the epitome of a one-party system at the time (Key, 1949), displayed factional rather than party politics. The political battles were between the state administration headed by Carl Bailey and the leader of the federal office holders, Homer Adkins, who was responsible for having Fulbright fired as President of the University. When Adkins decided to try for the U.S. Senate seat, then occupied by Hattie Caraway, the Bailey faction answered with Congressman Fulbright as their candidate. Fulbright acted with caution, though; only after a thorough canvass of the influentials in every county had convinced him that his candidacy had substantial support, did he announce.

Having established his reputation as an internationalist with the Fulbright Resolution, the candidate decided to conduct an issue-oriented campaign addressed to the problems of international peace and Arkansas welfare. He soon found out that in the Arkansas political climate, candidates, not issues, counted, and as a candidate he had to answer for his stance toward labor, civil rights, and the New Deal. He staunchly denied that he was a New Dealer: "I do not acquiesce in the continuation of unnecessary bureaus, bureaucratic control and regulation by bureaucratic fiat. I disapprove of legislation by executive order and such noble experiments as the Fair Employment Practices Committee" (Fulbright, 1944a). He expressed dissatisfaction with recent Supreme Court interpretation of the Constitution, stating that needed changes should be made by legislation or amendment (Fulbright, 1944b). Unalterably opposed to federal regulation of purely local functions of state government, he objected to federal control of education (Fulbright, 1944c).

The charge of his being pro-labor had come about because of his endorsement by the C.I.O. It was a serious charge in a state in which labor in the minds of many was associated with foreign doctrines wholly alien to Americanism. Judging from his generally unfriendly attitude towards labor, one can only conclude that the C.I.O.'s endorsement was an option for the lesser evil.2 With respect to the rights of blacks, Fulbright fully as serted his southern identity:

I am not for Negro participation in our primary elections, and I do not approve of social equality...I am like you, a citizen of Arkansas and the South, devoted to Southern traditions and ideals (Fulbright, 944d).

Veteran political observers predicted a close senatorial race which would make a runoff primary necessary. While Fulbright won more handily than expected, he had not enough votes to avoid the second primary with his closest competitor, Adkins. No love was lost between the two candidates. Adkins was a ruthless opponent and not at all hesitant to play up to the prejudices of the voters. Fulbright, though never allowing himself to use the crasser ad hominem charges publicly, defended his case in occasionally quite forceful language. ${ }^{3}$ Adkins' approach to discredit Fulbright focused on the alleged unsavory qualities of Fulbright's mind. He 


\section{Kurt K. Tweraser}

charged that Fulbright had an "Oxford-Vienna bred mind" and urged the voters to repudiate the candidate "representing the foreignisms and strange philosophies so incompatible with the American government we all know, love, and are fighting to preserve" (Adkins, 1944). However, all appeals to prejudice proved to be in vain; Fulbright won the runoff primary by a margin of almost 32,000 votes. 4

Why did Fulbright win? First of all, he had presumably made a favorable impression upon Arkansas voters with the way he had handled him self as a freshman in Congress. At this early stage in his career, he successfully conveyed to his constituents a sense of his competence. He also won because he successfully convinced the voters that he was one of them in the one issue area in which the slightest deviation would prove deadly to political survival. He conveyed a sense of identification with them. Voters apparently came to the conclusion that his southern identity was not just a face put on for campaign purposes, but was an essential part of his self-image. Furthermore, he conveyed a sense of empathy with these constituents on the war and peace issue. For once, being identified as an internationalist helped rather than hurt him with the average voter. As the Gazette editorialized:

The people of this state had heard from him the words that expressed their hopes and prayers for a world free of horrors... Against this new appeal to voters who were men and women with hearts oppressed by war, the old- time political campaign was in vain. Old fetishes, old bogies and old taboos had lost their power.... The cries that once might have influenced the ballot were drowned in the thunder of guns (Arkansas Gazette, 1944).

Qualification, identification and empathy were all helpful in building constituency trust. The heavy campaigning provided the personal contact enabling the voters to judge the candidate as a person.

The essential part of his self-presentation: in business, a conservative; in international affairs, a progressive; in race, a Southerner, corresponded with the expectations of his primary constituency. He found solid support in the business community. Indeed, it enabled him to compete with the enormous campaign spending of his opponents. 5 Needless to say, the black and the labor vote lay outside his primary constituency.

In subsequent years, Fulbright successfully maintained a reliable set of constituencies, so much so that he went unopposed in the primaries in 1950 and 1956. Substantial opposition to Fulbright in the form of a viable candidate did not appear simply because the powers that were in the state did not provide any support for a challenger.

In 1950, the A.F.L. was so incensed with Fulbright's record on labor legislation that they searched in vain for a candidate to oppose him. On the other side of the political spectrum, former Governor Benjamin Laney, a vigorous states righter, considered running. So were Sidney McMath and Homer Adkins, the rumors had it. In the end, there was no opposition, and Fulbright congratulated his political intimates in the state for having discouraged all opposition (Fulbright, 1950b). His models of representation corresponded nicely with Arkansas political reality.

Fulbright pursued the same strategy of preventive maintenance in 1955-1956. As early as the fall of 1955 , he campaigned to discourage opposition. Rumors spread in the Spring of 1956 that Benjamin Laney would again try to run for the Senate seat on a racist platform and had approached Homer Adkins, Fulbright's old political foe, to aid in the campaign. Apparently, Adkins was at that time close to Witt Stephens, an investment banker on the rise to great fortune. And as a close associate of Fulbright told him, Homer was aware of his obligation and knew that Witt did not want Fulbright to have opposition (Erickson, 1956). In the end, Fulbright was again 
unopposed and easily defeated the Republican opponent in the November election. 6 His models of representation were still effective.

Not facing opposition after 1944 had its disadvantages. The greater the opportunities for Fulbright to reach positions of influence in Washington, the greater the strain in the allocation of resources between the Hill and home. This is, of course, a dilemma built into the require ment that Congress be a representative and a legislative institution simultaneously. It appears that Fulbright's shift in the allocation of resources away from re-election to the making of public policy led to a gradual erosion of his local orientation, or so it seemed to his constituencies. His staff was clearly aware of the image problem the Senator faced in the late fifties. "I do not think that the man in the street really knows much about him," wrote one of his staffers in a memo to other staff members. Sporadic speaking trips in the state and precious little radio and TV work were not enough to get the Senator's name and face before the Arkansas public (Jones, 1960). Staffers clearly recognized that the original primary constituency was deteriorating, that it was time to establish a campaign organization and refurbish Fulbright's home image. From the "shoulds" listed in the memo, paraphrased below, one gets a vivid picture of the deficiencies in Fulbright's home style.

\begin{abstract}
We should continue compiling lists of county political leaders.
We should work out some systematic plan to contact the people who supported us, periodically. We have not cultivated them sufficiently to keep them actively interested in Senator Fulbright's welf are and political future.
\end{abstract}

We should institute a regular TV and radio series and the Senator, while traveling in the State, should make every effort to appear on local radio and TV stations.

The Senator should be encouraged to attend as many functions here in Washington as possible when some delegation from the State is here; the Senator does not like to do this, but it is in his best interest. We should try to influence him to see more people from the State who come to the office. He has established a reputation for being unapproachable.

The Senator should pay more attention to the Arkansas press representatives here in town.

We should expand our publicity routine items such as approval of various Federal Grants for the State.

We should have an up-to-date list of the officers and leaders in various Arkansas specialinterest groups.

We should make an effort to cultivate the various women's groups in the state, etc.

His image problem was aggravated when in 1959 he gave up the chair manship of the Banking and Currency Committee and became chairman of the Foreign Relations Committee. Fulbright remarked plaintively:

In view of the fact that I am Chairman of the Committee on Foreign Relations, no matter whatI may do for local interests in the State, thepress will always play up the foreign aspect ofmy activity above the local. I have often notedthat while practically everything I may say aboutour foreign relations is printed, the press oftenoverlooks noticing the things I say or do aboutState and local matters (Fulbright, 1960b).

Fulbright had reached the peak of his Washington career. The resource requirements of his Hill job made it almost impossible to meet the expectations of attentiveness at home. He was propelled to move from a protectionist to an expansionist stage in his constituency career when Orval Faubus, then in his fourth term as Governor, began to make ominous noises about national issues such as foreign aid and the communist conspiracy. It was generally agreed that Faubus would have had a good chance of defeating Fulbright. 7 Fulbright knew that the only way to ward off a Faubus candidacy for the senatorial seat was to embark upon a vigorous fence-mending campaign to impress upon prospective candidates the riskiness of a challenge. 
Fulbright had been the bete noire of right-wing forces for quite some time. Their hatred of Fulbright was increased when he protested to the Pentagon about its "cold war forums" which he said were being misused to indoctrinate civilians with the prejudices of "right-wing radicals." In response to the so-called "muzzling" of the military, a wide range of right wingers targeted Fulbright. Among them were Billy James Hargis from Tulsa, a powerful crowd-getter and fund-raiser who used a blend of fundamentalist religion and rabid anti-communism to get a national audience; and H.L. Hunt, the Dallas oil millionaire eccentric. Fulbright had to spend a good deal of his time and energy in his Fall 1961 pre-campaign dealing with the issues of muzzling the military and his alleged softness on communism.

Eventually, Faubus found it the better part of wisdom to go after a sure fifth term as Governor rather than an unsure first term as Senator. For a while, it seemed that Fulbright might be unopposed again; then, two days before the filing date, Winston Chandler, an obscure trucking firm operator from Little Rock, emerged as the challenger.

Apparently, because of the obscurity of Chandler, Fulbright was advised not to make an all-out campaign effort aside from a number of personal appearances, some publicity in the newspapers and a half-hour appearance on statewide television just before the election. No billboards, bumper stickers, campaign buttons, cards, etc., were used (Williams, 1962). Some old hands, however, urged the Senator to spend more time just on regular old-time handshaking and meeting of friends from years gone by.

That kind of a trip is needed badly to secure the kind of vote we want you to have. I have talked to quite a few of your old friends who tell me you haven't even written them in several years acknowledging their existence, and they apparently resent having been ignored (Huff,
1962 ).

Chandler, with financial support from right-wingers, attacked Fulbright primarily on his foreign policy record and there was enough anti-Fulbright sentiment in the state to produce a surprisingly high tally for the challenger (129,987 or almost $33.9 \%)$.

The Republicans apparently selected Arkansas as one of the target states in the Fall election of 1962. Under the leadership of Winthrop Rockefeller, who had tried hard to revitalize a small moribund party of "postoffice" Republicans, and the National Republican Committee, who delegated Senators Goldwater and Tower to campaign in the state, they concentrated on Fulbright. Their candidate, Kenneth G. Jones, an orthopedic surgeon from Little Rock, was, however, not up to the task. He mouthed the familiar right-wing charges against Fulbright: muzzling the military, his consistent work for the destruction of American national sovereignty, his sympathy for the U.N., his consistently pro-socialistic voting record, his general attitude of high-hat, stuffed-shirt aloofness, his over-educated eggheadedness and lack of the common touch. The massive effort of the Republicans convinced Fulbright that this time he had to go all out and conduct a campaign with all the trimmings. It even convinced the leadership of the Democratic party in Arkansas to unite for once. The outcome was an overwhelming victory for the Democratic candidates. Fulbright won with 182,150 votes over Jones with 80,474 .

Fulbright's personal constituency was intact. He had a lucky hand in picking his closest political advisers and confidantes. They were his staff assistants, all of them with an Arkansas background and extensive knowledge of Arkansas politics; his wife, a gregarious and charming campaigner, from whom he drew emotional sustenance for his political work; and a few political pros in Arkansas, such as Jack Pickens, Bill Darby, and Marlin Hawkins.

The coalition of his strong supporters and loyalists had to be held together with a variety of explanations, since he was dealing here with heterogeneous constituencies. 
The message he wanted to convey, first of all, was: In work on the Hill, I am effective for you. The technique used was a massive letter campaign, partly out of the Senator's campaign office to reach teachers and county committeemen, partly by approaching trusted friends to write letters to their friends in the business community with arguments provided by the Senator's office. Thus, thousands of letters went out to lawyers, doctors, bankers, car dealers, the poultry folks, wholesale grocers, soil conservation supervisors, cotton ginners, fish farmers, and alumni of the University of Arkansas. The letter campaign was, of course, reinforced by telephone calls by the Senator himself, by press releases, by radio spots and television appearances, and an occasional dramatic gesture.8

Friends of the military were informed by no less than the Chairman of the House Un-American Activities Committee, Francis Walter, that the idea that Fulbright was soft on communism was ridiculous (Walter, 1962). Lest anybody get the notion that Fulbright was a moderate on race, he solicited a letter of support from the uncrowned king of the Southern caucus, Senator Richard Russell, which testified that he had been a consistent and resourceful champion of the rights of the States and a staunch defender of southern traditions (Russell, 1962). The oil people in Arkansas were reminded by Senator Kerr from Oklahoma that Bill Fulbright was one of the best friends the oil industry had in the Senate (Kerr, 1962).

In order for this campaign to be effective, Fulbright could fall back upon a voting record sufficiently close to the expectations of his primary supporters to permit trust, that all-important ingredient in the representative-constituent relationship. Fulbright was eminently successful in reinforcing his close supporters; he sensed, though, that he had problems with the average voter. In order to get a handle on establishing trust with them, his office contacted aggressive young lawyers in all counties to provide them with an analysis of the vote breakdown in the Democratic primary, especially in all the boxes in which Chandler had done reasonably well. Typical is the following response:

As to the reasons for the vote in Little River County, Senator Fulbright is known all over the world quite favorably, however...there are alot of people in the rural boxes, who do not know of Senator Fulbright...and one name means as much to them as another. On the other hand, in some of the boxes, some of them do not believe in foreign aid at all.... Then there is the issue of the World Court, United Nations and other things upon which the people differ quite a bit, which leads me to believe, that if the Senator can get a 2 to 1 vote over the County and the State that he will not be doing a bad job (Finley, 1962).

In a massive grass-roots campaign, Fulbright placed ads in every county newspaper detailing what he and the Arkansas delegation had done for each county. This helped with name recognition and also countered the charge of having been a "do-nothing-for Arkansas" Senator. Furthermore, to increase the folksy aspect of his campaign, Fulbright prevailed upon his fraternity brother, Chester Lauck, better known as Lum of the famed "Lum and Abner" series, to do a few "Visit with Lum" programs on radio letting country store characters chat favorably about Fulbright.

The most vexing issue for Fulbright was foreign aid. It was probably the major reason for the sizable Chandler vote that it was a difficult issue to explain to people with a background in the area. With regard to other issues, either Fulbright was unwilling to expend electoral capital (Yingling, 1962), or an appeal to the bread-andbutter issues made it unnecessary. With respect to foreign aid, explanation had to become education. It is an expensive electoral enterprise to tell constituents that they have to temper their parochialism and surrender stereotypes. Nevertheless, Fulbright bravely tackled the issue and made a lengthy broadcast on foreign aid. He employed basically two arguments in favor of it. One, close to $80 \%$ of foreign aid was spent in the U.S. itself, the largest single item being farm products, with obvious material implications for Arkansas. Second, support of foreign aid is a major factor in combating communism (Fulbright, 1962). 


\section{Kurt K. Tweraser}

The issue underlying foreign aid was a much larger one; it was one of unilateralism vs. multilateralism. It was a class between those who were convinced that the final resolution of the dilemmas of the contemporary era could be found in military terms and those who believed that the long-term interests of the United States required institutionalizing an elaborate network of cooperative international arrangements (Lerche, 1964). In this emotionally charged area, the unilateralists expected a delegate justification, that is, following the constituents' wishes. Yet, given his overall mix of representational models, this was precisely the area in which Fulbright insisted on a trustee justification.

\section{Conclusions and Discussion}

The essay began with the assumption that political actors are different models of beliefs in different issue areas. In analyzing a legislator, the assumption of issuerelated variability aids greatly in explanation. Fulbright's perceptions of the irrational nature of politics endured in time and cut across issue contexts. How did Fulbright cope cognitively with irrationality in politics and human nature? During the period discussed, he had three clusters of cognitive strategies available: in foreign policy, a cluster we might term the rationalist power politics paradigm; in public welfare, a particularist issue politics paradigm; and in race, a "no politics" paradigm.

The rationalist power politics paradigm focuses almost exclusively on the nation-state as they key actor in international politics in general, and on the great powers in particular. Issues are raised by nations only; the dominant issues are war and peace. These issues are resolved through concentration of power in the major nation-states in the form of a balance of power. The balance of power in turn gives rise to cooperative and accommodationist foreign policies. The cognitive style in highly universalistic, emphasizing general ideas, long-range problems, and neglect of detail. The nation-state is conceived as a unitary rational decision-maker. The status relationship between representative and represented is one of trusteeship designed to protect the unitary character of the decision-maker in foreign policy. 9

In domestic public welfare, the predominant cognitive style is partisanship in a pluralist political culture. The allocation of values involves an incremental process of adjustment in mixed cooperative-conflictual relationships among national political parties, interest groups, and ad hoc coalitions on a multiplicity of issues. The government is not conceptualized as a unitary actor but a conglomeration of players in the games of public policy. The corresponding model of representation is the politico, forever shaping and adjusting to the various configurations of bargaining.

In race, the predominant cognitive style is traditionalism, indicating a belief that the problem is insoluble through the political process. Benign inactivity of the government is the decision-making model deemed appropriate, the adjective "benign" referring to Fulbright's belief that education might bring about change in the long run. The model of representation is the instructed delegate humoring the prejudices of his constituency.

We find some congruence also between models of representation and home style. In race and domestic public policy, representation is viewed as process and politics, in foreign affairs as education. In foreign affairs, Fulbright was willing to suffer electoral losses in order to see his policy preferences enacted; in the other areas, he was willing to adjust his preferences to prevailing political circumstances and mores. 
These are very crude generalizations, and refinements are needed in each broad issue context. Quite clearly, in foreign policy, some areas are closer to domestic politics than others, vide foreign economic policy and foreign aid. Indeed, it might be fallacious to think of issue areas as being determined by a single model of representation. Rather, we may think of each issue area as a mix of trustee, politico and delegate assumptions guiding the representative. While the mix demonstrates constancy over time--with trusteeship controlling foreign policy and delegateship the race issue, changing configurations of power in foreign policy and a changing political culture in race politics were bound to induce changes in the mixes. In foreign policy, change is especially apparent in the realm of presidentialcongressional relations. Needless to say, Fulbright's strict instructed delegate approach to the race issue also changed with the increasing electoral prowess of the black vote in Arkansas in the late 1960's.

Furthermore, it is entirely possible to arrive at a more mundane alternative analysis of Fulbright's political behavior, alternative to the constructs used by the author, but just as compatible with the facts. The difference between acting as instructed delegate in racial matters, but as a trustee on foreign policy issues is explicable in terms of Fulbright's belief in the necessity of re-election. His Arkansas constituents cared deeply about civil rights--and therefore he went along with them-but really had no firm views on foreign policy--so he could so as his own conscience and intellect dictated. On the issues in the area of public welfare, he did what any politico does--grabbed what he could for his voters, a purely political exercise. In foreign policy, too--and this is perhaps too unkind--one wonders how much of his wholehearted support for, let us say, the Marshall Plan or free trade was due to the possibility it provided for Arkansas agricultural products. Viewed in this light, the fundamental orientation of his beliefs was perhaps not as different in domestic and foreign policy as postulated by Fulbright. Both involved political factors--obviously on somewhat different levels--of the kind that any politicians would normally find it necessary to consider, and quite properly so.

Still, I submit that the constructs I used help to move discussion of Fulbright's ideology beyond the moralizing which has characterized comment on his race politics and his foreign policy. They give us a more accurate view of the early Fulbright, before his role in the Vietnam war made him what future generations will regard as a seminal figure in American history.

\section{Endnotes}

1. It is only fair to add that Fulbright's belief changed after 1964 on issues of presidential-congressional relations, the role of public opinion, and even race. But it also seems fair to say that from his entry into politics in 1943 to 1964 , he did analyze "reality" with the help of the models mentioned.

2. While Fulbright was for collective bargaining in general, he fully approved of the Taft-Hartley Act. As for Fair Labor Standards, he was squarely for maintaining wage differentials to attract industries to Arkansas. Southern labor interests are discussed by Irish $(1952,1960)$.

3. How deeply he was disturbed about the political ruthlessness of his of his opponent is indicated by some of Fulbright's private remarks comparing Adkins to Hitler. "I have a very graduated idea what a devil he was...And the idea of his coming in as Senator and me continuing as Congressman didn't appeal to me at all" (Johnson \& Gwertzman, 1968).

4. Fulbright, 117,126; Adkins, 85,161. The Republican opposition was insignificant, and Fulbright won, 182,499 to 31,942 (Arkansas Democrat, 1955). 


\section{Models of Representation and Re-election Strategies, 1942-1962}

Fulbright, J.W. (1950a). Letter to John E. Wells, Little Rock, June 22. James William Fulbright Papers, University of Arkansas, BNC, F38.

Fulbright, J.W. (1950b). Letter to Jack Pickens, March 5, 61:2, 2:1.

Fulbright, J.W. (1951). "Congressional Investigations: Significance for the Legislative Process," University of Chicago Law Review, 18, 440- 448.

Fulbright, J.W. (1953-54). "Julian S. Waterman--A Memorial," Arkansas Law Review and Bar Association Journal, 8, 64-66.

Fulbright, J.W. (1958). Statement, Congressional Record, Aug. 27, 85th Congress, 2nd Sess., $19852-$ 19853.

Fulbright, J.W. (1960a). United States Foreign Policy. Congress, Hearings, Committee on Foreign Relations. Washington, 86th Cong., 2nd Sess., 213.

Fulbright, J.W. (1960b). Letter to F.B. Baker, Jr., Paris, Ar., Aug. 13., 61:1, 1:2.

Fulbright, J.W. (1961). "American Foreign Policy in the 20ah Century under an 18th Century Constitution," Cornell Law Quarterly, 47, 1-13.

Fulbright, J.W. (1962). Broadcast on Foreign Aid, TV Script, General Election, 61:3, 7:5.

Fulbright, J.W. (1963). "Is Government by the People Possible?" Speech, New York, Fund for the Republic, January 21.

Fulbright, J.W. (1964). Old Myths and New Realities. New York: Random House-Vintage.

Fulbright, J.W. (1966). "Education for a New Kind of International Relations." Speech, Annual Meeting of the Swedish Institute for Cultural Relations, Stockholm.

Fulbright, J.W. (1967). "Human Nature and the Cold War," Speech, Wilmington College, Ohio.

Huff, E. (1962). Memo to Fulbright, June 13, 61:3, 3:5.

Irish, M.D. (1952). "Recent Political Thought in the South," American Political Science Review, 46, $121-$ 141.

Irish, M.D. (1960). "Political Thought and Political Behavior in the South." The Western Political Quarterly, 13, 406-420.

Johnson, H. and Gwertzman, B. (1968). Fulbright: The Dissenter. New York: Doubleday.

Jones, H. (1960). Memo to John Erickson, March 29, 61:3, 3:4.

Kerr, R.S. (1962). Letter to Mr. Puterbaugh, McAlaster, Ok., Sept. 4, 61:3, 8:3.

Key, V.O., Jr. (1949). Southern Politics in State and Nation, New York: Knopf.

Lerche, C.O., Jr. (1964). The Uncertain South; Its Changing Pattern of Politics in Foreign Policy. Chicago: Quadrangle Books.

Lilienthal, D.E. (1971). The Journals of David E. Lilienthal, Vol. V, The Harvest Years. New York: Harper \& Row.

Miller, W.E., and Stokes, D.E. (1963). "Constituency Influence in Congress," American Political Science Review, 57, 45-56.

Mitchell, W.C. (1958). "Occupational Strains: The American Elective Public Official," Administrative Science Quarterly, 32, 210-228.

Pitkin, H. (1972). The Concept of Representation. Berkeley: University of Califomia Press.

Physicians for Fulbright Committee (1962). Letter to doctors, 61:3, 6:1.

Russell, R. (1962). Letter to Fulbright, Aug. 29, $61: 3,8: 3$. 


\section{Kurt K. Tweraser}

Tweraser, K. (1971). The Advice and Dissent of Senator Fulbright: A Longitudinal Analysis of His Images of International Politics and His Political Role Conceptions. Unpublished doctoral dissertation, The American University.

Tweraser, K. (1974). Changing Patterns of Political Beliefs: The Foreign Policy Operational Codes of J. William Fulbright, 1943-1967. Beverly Hills: Sage Publications.

Wahlke, J.C., Eulau, H., Buchanan, W., and Ferguson, L.C. (1962). The Legislative System: Explorations in Legislative Behavior. New York: Wiley.

Walter, F.E. (1962). Letter to Fulbright, Sept. 4, 61:3, 8:3.

Williams, L. (1962). Memo to Fulbright, May 21, 61:3, 3:5.

Yingling, J. (1962). Memo to Fulbright, Subject: Negro vote, Sept. 25, 61:3, 8:2. 